\title{
Countering Violent Extremism in America
}

Lorenzo Vidino and Seamus Hughes

Program on Extremism

Center for Cyber \& Homeland Security 


\section{About the authors:}

Dr. Lorenzo Vidino is the director of the Program on Extremism at George Washington University's Center for Cyber and Homeland Security.

Seamus Hughes is the deputy director of the Program on Extremism. He previously worked at the National Counterterrorism Center (NCTC), serving as a lead staffer on the U.S. government's efforts to implement the national countering violent extremism strategy. The views expressed are his own and do not represent the position of the NCTC, the Intelligence Community, or the U.S. Government 


\section{Table of Contents}

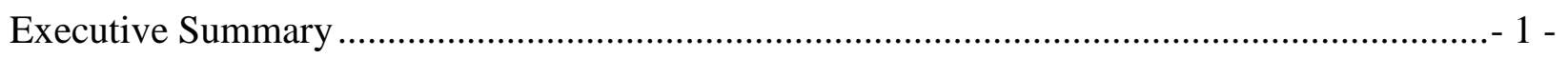

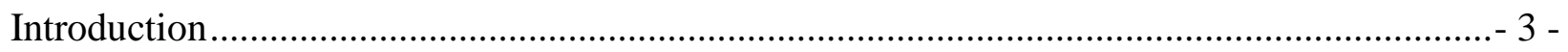

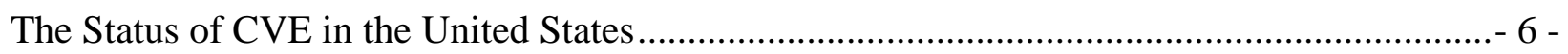

The Three-City Pilot and the White House Summit ....................................................... 7 -

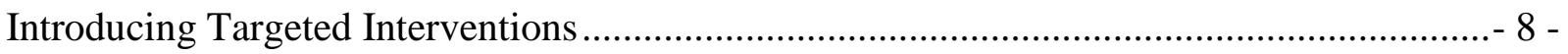

The Debate within American Muslim Communities ......................................................- 10 -

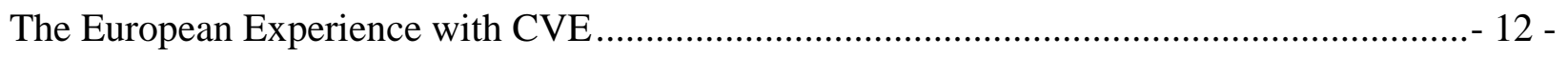

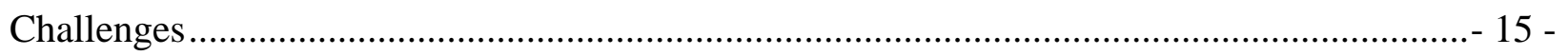

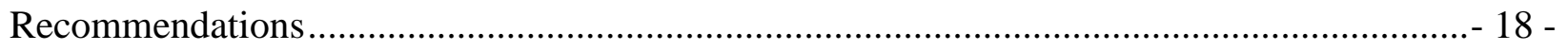




\section{Executive Summary}

Over the last decade, governments throughout the world have invested substantial resources aimed at devising Countering Violent Extremism (CVE) strategies. CVE is a delicate exercise that, if properly implemented, can help sway young people from radicalizing, thereby saving lives and enabling law enforcement to better concentrate on those who have made the leap into violent militancy.

The United States has lagged behind many European countries in creating a comprehensive CVE approach, largely because its homegrown violent extremist threat is relatively low. Only in 2011 did the U.S. launch a formal CVE strategy and its implementation has been disjointed and underfunded. The Boston Marathon bombing and later the rise of ISIS triggered a renewed focus on CVE, culminating in a recent high-profile White House summit. Part of the revamped effort includes pilot programs in three cities, each with a distinct approach: Minneapolis-St. Paul's focused on societal-level concerns, Los Angeles' on community engagement, and Boston's on interventions with radicalized individuals.

Targeted interventions appear to be the next frontier of America's CVE efforts. Officials increasingly see the importance of expanding CVE's focus on community engagement to include targeted interventions with individuals who have become radicalized but have not yet mobilized to violence. Nonetheless, targeted interventions so far have been deployed at the whim of local authorities, rather than via an articulated and tested methodology.

Successful implementation of the administration's CVE goals faces key challenges:

- Lack of funding: Resources devoted to CVE have been highly inadequate, and CVE units within each relevant agency remain understaffed.

- Lack of lead agency: CVE efforts appropriately involve an array of agencies at the national and local levels. Yet there needs to be a single responsible point of contact for coordination, public advocacy matters, and congressional oversight.

- Resistance from Muslim communities: Some Muslim civic groups embrace CVE, while others decry it as a surveillance ruse or an effort that singles out Muslims. Successful CVE efforts need support from a broad community cross-section.

CVE trends in various European countries, where authorities have implemented ambitious strategies for over a decade, offer useful pointers to U.S. officials. European authorities display diminished enthusiasm for large, preventive programs due to high costs and difficulty in empirically determining effectiveness. Individual interventions are, on the other hand, increasingly popular because they are cost-effective and easier to evaluate. While interventions

$-1-$

Program on Extremism - 2000 Pennsylvania Avenue NW - Suite 2210 - Washington, DC 20052 https://cchs.gwu.edu/program-extremism 
do not work in all cases, their threat reduction effect is a relief for Europe's overwhelmed law enforcement and intelligence agencies.

Because the radicalization process is complex and highly variable, European de-radicalization efforts seek to tailor interventions to each situation. This complicates efforts to develop broad national programs with easily replicable best practices. It also requires investing time to set up a network of community leaders with appropriate competencies. As Muslim communities are not monolithic, European authorities have struggled to identify appropriate partners among myriad organizations. Engaging many local partners with roots in specific communities - rather than relying on a national gatekeeper - is seen as an effective way to harness the full potential of Muslim communities.

Moreover, increasingly aware of the need to be more inclusive, European authorities have begun to describe their efforts using the language of "safeguarding." Radicalization is presented as a problem like gang recruitment, drugs, or pedophilia - and thus community leaders and teachers have a duty to report cases of young people falling prey to such a social ill.

The U.S. does not need to replicate Europe's most ambitious CVE efforts, as it faces a significantly smaller radicalization challenge. General preventive measures, particularly those promoting socio-economic development, should be implemented only in limited cases, as American Muslim communities generally enjoy high levels of integration. Engagement and other trust-building initiatives are useful and should be continued.

The most pressing need at this stage is for the administration to build a carefully crafted system for interventions as a potential alternative to prosecution. Working with civil rights advocates, the government should provide guidance on minimum standards for intervention efforts that address the specific roles of government and communities, as well as the legal parameters of interveners who currently place themselves at risk of liability if interventions go awry. While interventions are best implemented at the local level, they require a high-level framework and clear guidance from federal officials.

$-2-$

Program on Extremism - 2000 Pennsylvania Avenue NW - Suite 2210 - Washington, DC 20052 https://cchs.gwu.edu/program-extremism 


\section{$\underline{\text { Introduction }}$}

On a snowy night in November 2014, the U.S. Attorney for the District of Colorado and officials from the Federal Bureau of Investigation (FBI), Department of Homeland Security (DHS), and National Counterterrorism Center (NCTC) gathered at the Abu Bakr mosque in Denver. ${ }^{1}$ An audience of religious leaders, parents, and teenagers filled the room. The participants engaged in a three-hour conversation on a topic few in the room had previously discussed in public: the radicalization of young Americans.

A month earlier, three teenage girls from Denver (one as young as fifteen) had been stopped by German authorities at the Frankfurt airport. The girls were in transit to Turkey in an attempt to join ISIS (Islamic State in Iraq and Syria) in Syria. ${ }^{2}$ If not for a last-minute intervention of U.S. and German officials who scrambled to act after frantic calls from one of the girls' fathers, the teenagers likely would have joined the thousands of other Western recruits drawn to ISIS territory by a sophisticated recruiting campaign. ${ }^{3}$ Shaken by the incident, the Abu Bakr mosque's leadership had organized the meeting and invited government officials as well as members of surrounding mosques.

Included in the night's agenda was the Community Awareness Briefing (CAB), a threat briefing perhaps better understood as a storytelling device. ${ }^{4}$ Instead of the typical government report filled with statistics on attack techniques and lists of radicalization indicators, the CAB attempts to humanize Americans who have joined terrorist groups by telling their stories, exploring who they were before radicalizing, and the ordeal experienced by family and friends they left behind. The CAB attempts to bridge the divide between the trends in terrorist recruitment detected by law enforcement agencies nationwide and the information communities need to identify a potential wayward youth. ${ }^{5}$ The CAB has increased in relevance as the number of Americans attempting to join ISIS steadily climbs.

The CAB highlights an important yet often overlooked reality: There was a time before these radicalized individuals attempted to become involved in terrorist activities, a time when someone -- a family member, a soccer coach, or even a friend -- saw some concerning sign that the young person could be embarking on a path towards militancy. In effect, the CAB argues that there was

\footnotetext{
1 “After Girls’ Jihadi Quest, a Focus on Outreach,” Associated Press, November 14, 2014.

2 “ISIS Used Predatory Tools And Tactics To Convince U.S. Teens To Join” National Public Radio, December 11, 2014.

3 “US Official: 3 Denver girls play hooky from school to tried to join ISIS,” CNN, October 22, 2014; Director of National Intelligence James R. Clapper, Statement on the Worldwide Threat Assessment Before the Senate Armed Services Committee, February 26, 2015.

${ }^{4}$ NCTC Director Nicholas Rasmussen, Statement on the Current Terrorist Threat to the United States Before the Senate Select Committee on Intelligence, February 12, 2015.

${ }^{5}$ Ibid.
} 
a stage when these young people were still persuadable -- before they made a choice that irrevocably altered the government's ability to take any action other than arrest.

The Denver meeting was one of dozens of similar community briefings held in the past year, a sign of American authorities' growing enthusiasm for Countering Violent Extremism (commonly referred to as CVE). An inherently amorphous term ${ }^{6}$, CVE can be described as measures aimed at preventing individuals from radicalizing and reversing the process of those who have already radicalized. ${ }^{7}$ CVE measures range from establishing dialogue platforms with communities in which the risk of radicalization is perceived to be particularly heightened, to personalized interventions seeking to change the radical views of specific individuals. In substance, CVE constitutes an array of non-repressive initiatives that seek to address behaviors that could potentially lead to terrorism-related activities.

Over the last decade governments throughout the world have invested substantial resources aimed at devising CVE strategies, most of them aimed at countering Islamist-inspired radicalization. The United States has lagged behind in creating a comprehensive CVE approach, instead focusing on a series of isolated programs such as the CABs. Though the US has a domestic CVE strategy, its efforts are disjointed and underfunded. Several overlapping reasons account this deficiency, including:

- the limited number of terrorism cases in the US;

- the effectiveness of tough law enforcement techniques, at least from a narrow, statistical perspective;

- the confusion generated by the overlap of several agencies dealing with radicalizationrelated issues in various jurisdictions;

- a national culture, reinforced by core constitutional values protecting freedom of conscience, that does not believe law enforcement should grapple with ideological and even indirectly religiously-related issues.

This report seeks to provide a primer on these dynamics. First, it analyzes the status quo of CVE in America, detailing the latest initiatives and the challenges they face. The second part summarizes the current CVE trends in various European countries, where authorities have implemented ambitious strategies for over a decade, and whose experience can therefore offer useful pointers to U.S. officials. Finally, the report provides recommendations aimed at

\footnotetext{
${ }^{6}$ Steven Heydemann, “Countering Violent Extremism as a Field of Practice,” USIP Insights, Issue 1, Spring 2014.

${ }^{7}$ The U.S. government defines CVE as "efforts focused on preventing all forms of ideologically based extremist violence, to include prevention of successful recruitment into terrorist groups. It is distinct from disruptive actions which focus on stopping acts of terrorism by those who have already subscribed to violence.” (See Factsheet: A Comprehensive U.S. Government Approach to Countering Violent Extremism, available at: http://www.dhs.gov/sites/default/files/publications/US\%20Government\%20Approach\%20to\%20CVEFact\%20Sheet.pdf).
} 
improving an often poorly understood and polarizing issue that, despite its many difficulties, is widely considered an indispensable part of a comprehensive counterterrorism policy.

-5 -

Program on Extremism - 2000 Pennsylvania Avenue NW - Suite 2210 - Washington, DC 20052 https://cchs.gwu.edu/program-extremism 


\section{The Status of CVE in the United States}

Released in August 2011, the U.S. government's CVE Strategy, entitled Empowering Local Partners to Prevent Violent Extremism in the United States, calls for a three-pronged approach: 1) enhance engagement with communities; 2) build CVE expertise; and 3) counter violent extremist propaganda. ${ }^{8}$ The strategy places the onus of prevention on local public safety officials and communities, with the federal government acting as a capacity-builder. As a senior White House official explained at the time: "Where the federal government can add value, we'll offer it. But often times, the best expertise and solutions for a community will be found in that community - in the local organizations, institutions and businesses that understand the unique challenges of that community." 9

The strategy was followed a few months later by a Strategic Implementation Plan (SIP), which outlined nominal roles and responsibilities for various departments and agencies. ${ }^{10}$ The SIP tapped the 94 U.S. Attorney's Offices throughout the country as the federal leads in the field for CVE-related community engagement and placed responsibility for implementation on four agencies: DHS, NCTC, FBI, and the Department of Justice (DOJ).

The strategy was developed partly in response to rising Islamist-inspired homegrown violent extremism. From 2009 to 2011, at least twenty Somali Americans from the Minneapolis-St. Paul area had absconded to Somalia to join al Shabaab, triggering a recognition within Washington that the problem had reached disconcerting levels. ${ }^{11}$ As the government struggled to organize against this concern, select communities across the country began to face the hard truth that a small but significant number of its youth were succumbing to recruiting efforts by violent extremists.

DHS, working with NCTC, and through various U.S. Attorney's Offices began to roll out new programs such as the abovementioned $\mathrm{CAB}$ and the Community Resilience Exercise (CREX). The CREX program sought to bring together law enforcement and American Muslim community members to address a hypothetical scenario of an individual appearing to radicalize to violence. ${ }^{12}$ The CAB and the CREX became the main tools of CVE-aimed community engagement in the nation.

\footnotetext{
${ }^{8}$ Available at: http://www.whitehouse.gov/sites/default/files/empowering_local_partners.pdf

${ }^{9}$ Remarks by Denis McDonough, March 6, 2011. Available at: https://www.whitehouse.gov/the-pressoffice/2011/03/06/remarks-denis-mcdonough-deputy-national-security-advisor-president-prepa

${ }^{10}$ Empowering Local Partners to Prevent Violent Extremism in the United States: Strategic Implementation Plan, December 2011. Available at: http://www.whitehouse.gov/sites/default/files/sip-final.pdf

${ }^{11}$ U.S. Senate Homeland Security and Governmental Affairs Committee, Violent Islamist Extremism: al-Shabaab Recruitment in America, March 11, 2009. Available at: http://www.hsgac.senate.gov/hearings/violent-islamistextremism-al-shabaab-recruitment-in-america

${ }^{12}$ CVE Engagement Activities - NCTC Classes. Available at:

http://www.dhs.gov/sites/default/files/publications/CVE\%20Engagement\%20Activities-NCTC\%20Classes.pdf
}

$-6-$

Program on Extremism - 2000 Pennsylvania Avenue NW - Suite 2210 - Washington, DC 20052 https://cchs.gwu.edu/program-extremism 
Forward-thinking U.S. Attorneys in places like Raleigh, Denver, and Sacramento decided to hold sensitive conversations with their local communities, particularly via the leaders of local mosques. The concept of CVE slowly began to take root through a coalition of federal and state officials who recognized that the status quo was inadequate. CVE efforts ebbed and flowed for the next three years through a small but dedicated cadre of federal, state, local, and community officials who took responsibility for implementing the White House's strategy despite little institutional backing or recognition.

\section{The Three-City Pilot and the White House Summit}

First the April 2013 Boston Marathon bombing and later the rise of ISIS triggered a renewed focus on CVE. On September 15, 2014, then Attorney General Eric Holder announced that the administration sought to focus its revamped CVE efforts on Boston, Los Angeles, and Minneapolis-St. Paul. ${ }^{13}$ The "Three City Pilot," as it became internally known, tasked authorities in those cities with developing local CVE frameworks aimed chiefly at ISIS-related radicalization. In the following months each city held a series of stakeholder meetings with nongovernmental organizations, community leaders, and federal, state, and local government officials. ${ }^{14}$ These processes culminated in presentations to the Summit on Countering Violent Extremism, a three-day event featuring high-ranking government officials and prominent community leaders hosted by the White House in February 2015.

Two of the three city frameworks have been publicly released. Boston's plan, A Framework for Prevention and Intervention Strategies, identifies seven focus areas ranging from addressing community isolation to foreign policy concerns to cultural competency. ${ }^{15}$ The twenty-page document is impressive in both its transparency and granularity. Each focus area has goals and proposed solutions, and outlines next steps. Particularly interesting is the second identified problem: "providing services to individuals before mobilization toward violent extremism is challenging when there is a lack of understanding regarding violent extremism and limited intervention programs." The framework calls for "surg[ing] resources to fund service providers to provide case management, individualized service plans, educational assistance and transitional job opportunities to vulnerable individuals." 16

So far the U.S. has had no systematic approach to intervene with radicalized individuals. Were Boston to establish such a program, it would represent a major shift in law enforcement's

\footnotetext{
${ }^{13}$ Speech by Attorney General Eric Holder, September 15, 2014. Available at: http://www.justice.gov/opa/video/countering-violent-extremism

${ }^{14}$ White House Fact Sheet, U.S. Government Approach to CVE, February 2015. Available at: http://www.dhs.gov/sites/default/files/publications/US\%20Government\%20Approach\%20to\%20CVEFact\%20Sheet.pdf

${ }^{15}$ A Framework for Prevention and Intervention Strategies, February 2015. Available at: http://www.justice.gov/sites/default/files/usao-ma/pages/attachments/2015/03/27/framework.pdf 16 Ibid.
}

$-7-$ 
approach to counterterrorism, similar to some European efforts (to be discussed below). Yet it remains unclear if the city will receive the necessary funding to implement such a program, as federal resources have been slow to materialize.

The Los Angeles Framework for Countering Violent Extremism, on the other hand, focuses primarily on enhancing existing community engagement events and "building networks" of public and private sector programs to address violent extremism. The policy document also calls for the creation of intervention programs, called "off-ramps." While lacking the granularity of the Boston framework, the Los Angeles plan does identify potential concerns of any intervention program, such as the need to consider legal liabilities for interveners. ${ }^{17}$ Minneapolis-St Paul has yet to publicly release its strategy but a fact sheet presented at the White House CVE Summit indicates a heavy focus on perceived drivers of radicalization, such as "lack of economic opportunity" and "difficulty in school.",18

The “Three City Pilot” thus suggests three distinct approaches: Boston's focused on radicalized individuals, Los Angeles' on community engagement, and Minneapolis-St. Paul's on societallevel concerns.

\section{Introducing Targeted Interventions}

Over the last few years, U.S. officials have increasingly understood the importance of expanding what has initially been an engagement-based CVE approach with the introduction of individualspecific interventions such as those described in Boston's plan. Already in 2012, the U.S. Senate's Homeland Security and Governmental Affairs Committee (HSGAC) had urged the executive branch to create a system to deal with radicalized individuals who have not mobilized to violence, highlighting the dearth of tools available to law enforcement agencies besides arrest:

The U.S. Government needs to develop options within Constitutional and statutory constraints for situations in which federal law enforcement, such as the FBI, comes in contact with an individual who is radicalizing. It is not law enforcement's or the Intelligence Community's role to seek to change an individual's beliefs protected by the First Amendment, as opposed to focusing on criminal conduct. An individual's family, friends, and local community and religious leaders are best suited to dissuading the individual from criminal activity as well as rolling-back the radicalization. The U.S. Government needs to resolve the extent to which federal law enforcement can share

\footnotetext{
${ }^{17}$ Los Angeles Framework for Countering Violent Extremism, February 2015. Available at: http://www.dhs.gov/sites/default/files/publications/Los\%20Angeles\%20Framework\%20for\%20CVEFull\%20Report.pdf

${ }^{18}$ Building Community Resilience: A Minneapolis-St Paul Pilot Program. Available at: http://www.dhs.gov/sites/default/files/publications/MinneapolisSt\%20Paul\%20Building\%20Community\%20Resilience\%20Program-Pilot\%20Fact\%20Sheet.pdf
}

$-8-$ 
information concerning radicalized individuals with family, friends, and local community and religious leaders. ${ }^{19}$

More recently senior administration officials seem to have embraced that advice. ${ }^{20} \mathrm{~A}$ year after the Boston Marathon bombing, Lisa Monaco, Assistant to the President for Homeland Security and Counterterrorism, spoke at Harvard University on this topic:

Parents might see sudden personality changes in their children at home-becoming confrontational. Religious leaders might notice unexpected clashes over ideological differences. Teachers might hear a student expressing an interest in traveling to a conflict zone overseas. Or friends might notice a new interest in watching or sharing violent material. The government is rarely in a position to observe these early signals, so we need to do more to help communities understand the warning signs, and then work together to intervene before an incident can occur. ${ }^{21}$

Some FBI field offices have attempted to implement what Monaco suggested, carrying out "improvised" targeted interventions rather than employing traditional law enforcement tactics. The FBI Denver field office deployed this approach in case of Shannon Conley, a local young woman they identified as intending to join ISIS. Rather than rushing to detain Conley, Bureau officials tried to convince her to desist from her plans, working with her parents and religious leaders to suggest pursuing charity work for Syrian refugees rather than engaging in violence. ${ }^{22}$ Authorities in Minneapolis tried a parallel approach last January in the case of an 18-year-old local man of Somali descent, Abdullahi Mohamud Yusuf, accused of seeking to join ISIS. ${ }^{23}$ Yusuf was released to a halfway house while his case was pending on the condition that he work with a group that promotes civic involvement. ${ }^{24}$

\footnotetext{
${ }^{19}$ Zachary Chesser: A Case Study in Online Islamist Radicalization and Its Meaning for the Threat of Homegrown Terrorism, U.S. Senate Homeland Security and Governmental Affairs Committee, 2012. Available at: http://www.hsgac.senate.gov/imo/media/doc/CHESSER\%20FINAL\%20REPORT\%281\%29.pdf

20 Assistant to the President for Homeland Security and Counterterrorism Lisa O. Monaco, Countering Violent Extremism and the Power of Community, April 15, 2014. Available at: https://www.whitehouse.gov/the-press-office/2014/04/16/remarks-assistant-president-homeland-security-andcounterterrorism-lisa-

${ }^{21}$ Ibid.

${ }^{22}$ U.S. vs. Shannon Maureen Conley, Criminal Complaint, U.S. District Court for the District of Colorado, July 2014.

${ }^{23}$ Miriam Jordan, “A Test Case for 'Deradicalization',” Wall Street Journal, May 6, 2015.

${ }^{24}$ In May 2015 Yusuf was ordered back into custody for violation of halfway house rules, even though the nature of the violation is unclear. For an overview of the case, see: Dina Temple-Raston, "Minnesota's Radical Experiment in Jihadi Rehab,” The New Yorker, May 15, 2015.
}

-9 -

Program on Extremism - 2000 Pennsylvania Avenue NW - Suite 2210 - Washington, DC 20052 https://cchs.gwu.edu/program-extremism 
The U.S. government appears increasingly willing to experiment with targeted interventions. ${ }^{25}$ This approach will likely be utilized in the case of minors, as U.S Attorney's offices are unlikely to charge underage individuals with material support to terrorism. Nonetheless, the use of targeted interventions so far has been unsystematic and lacks a clear framework. It is deployed at the whim of local authorities rather than via an articulated and tested methodology.

\section{The Debate within American Muslim Communities}

Several American Muslim advocacy groups, as well as some civil liberties organizations, have repeatedly expressed their skepticism or outright opposition to CVE initiatives. The American Civil Liberties Union (ACLU), the Council on American-Islamic Relations (CAIR), and the Brennan Center for Justice, for example, have criticized CVE as a form of government overreach. CAIR's Los Angeles branch, for example, has urged mosque boards to "decline requests from law enforcement to collaborate on CVE programs" and the Muslim Student Association West has announced the hiring of five "Anti-CVE Campaign Managers." 26 Some groups have also compared CVE to COINTELPRO, the FBI's covert surveillance of domestic political organizations during the height of the Cold War. ${ }^{27}$

Yet many other American Muslim organizations have displayed a more positive attitude towards CVE efforts. The Muslim Public Affairs Council (MPAC), for example, released its own community-led intervention scheme, the Safe Spaces Initiative. ${ }^{28}$ In Montgomery County, Maryland, the World Organization for Resource Development and Education (WORDE) has established an innovative form of public-private partnership aimed at addressing at-risk individuals. ${ }^{29}$ In the highly diverse American Muslim community - perhaps better described as a wide range of communities - opinions on CVE vary significantly. ${ }^{30}$

\footnotetext{
${ }^{25}$ White House Fact Sheet, U.S. Government Approach to CVE, February 2015. Available at: http://www.dhs.gov/sites/default/files/publications/US\%20Government\%20Approach\%20to\%20CVEFact\%20Sheet.pdf

${ }^{26}$ http://cve-cairla.nationbuilder.com/cve_asks_from_community_leaders; https://www.facebook.com/pages/MSAWest/111751672205901

${ }^{27}$ http://cve-cairla.nationbuilder.com/talking_points and http://theislamicmonthly.com/logging-it-all-cve-andschisms-in-the-muslim-community/

${ }^{28} \mathrm{http}: / /$ www.mpac.org/safespaces/

http://www.dhs.gov/sites/default/files/publications/Montgomery\%20County\%20MD\%20Community\%20Partnershi p\%20Model-WORDE\%20Report.pdf

${ }^{30}$ A telling and public example of this diversity of opinions is represented by the debate taking place within Minneapolis-St. Paul's Somali American community. The opinions range from those who oppose the CVE initiative introduced in the Twin Cities (Kadra Abdi, Ayantu Ayana, Ramla Bile, Mohamed H. Mohamed, and Julia Nekessa Opoti, “The Countering Violent Extremism Program institutionalizes injustice among Somalis,” Minneapolis Post, May 1, 2015) and those who enthusiastically embraced it (Abdi Warsame, Mohamed Farah, and Abdisalam Adam, “How Twin Cities Muslim leaders are trying to prevent extremism,” Minneapolis Star Tribune, April 15, 2015).
} 
Another criticism of CVE efforts is their singular focus on Muslims. ${ }^{31}$ These concerns are not unfounded. The administration's strategy, while not precluding other forms of extremism, states that "al-Qa'ida and its affiliates and adherents represent the preeminent terrorist threat to our country." 32 According to studies by the University of Maryland Study of Terrorism and Responses to Terrorism, between 2000 and 2013 the vast majority of attacks in the homeland were carried out by non-Islamist extremists. ${ }^{33}$ Yet $100 \%$ of federal CVE efforts are aimed at Muslim communities.

${ }^{31}$ Rabia Chaudry, “Countering Violent Extremism is an Uphill Battle,” Observer, April 14, 2015.

${ }^{32}$ Empowering Local Partners to Prevent Violent Extremism in the United States, August 2011. Available at: https://www.whitehouse.gov/sites/default/files/empowering_local_partners.pdf

${ }^{33}$ Erin Miller, START Research Highlight, "Terrorist Attacks in the U.S. Between 1970 and 2013: Data from the Global Terrorism Database (GTD),” November 2014. http://www.start.umd.edu/publication/terrorist-attacks-usbetween-1970-and-2013-data-global-terrorism-database-gtd 


\section{The European Experience with CVE}

Over the last decade, countries around the world have developed their own CVE strategies, many of them significantly more comprehensive and evolved than current American policies. The models that provide particularly relevant and replicable lessons for U.S. authorities are those of other democratic societies with relatively similar cultural, political, and social characteristics. The decade-long experience with counter-radicalization of several Western European countries can be particularly instructive. The pioneer in the field is Great Britain, which, in 2003, launched an initiative called Prevent to implement a comprehensive domestic CVE strategy. Despite its many revisions and widespread criticism, Prevent remains a model from which the European Union and most European governments draw inspiration. ${ }^{34}$

Over the last few years, largely motivated by the dramatic growth of the phenomenon of European foreign fighters traveling to Syria, many other European countries have introduced CVE measures. ${ }^{35}$ Most European strategies are not limited exclusively to the issue of radical Islamist-inspired violence. Yet, in reality, the vast majority of initiatives and resources (arguably a disproportionate percentage) are devoted to stemming Islamist extremism.

European CVE programs differ greatly from one another in terms of aims, structure, budget, and underlying philosophy, and each individual program is deeply shaped by the host country's unique political, cultural, and legal elements. Nevertheless, certain key characteristics and challenges are common to all European CVE programs.

First, in Europe as in America, CVE is somewhat of a catch-all term that encompasses three large macro-families of activities:

a) General preventive measures: These initiatives aim to challenge extremist ideas and influences in society; promote tolerant, moderate, and democratic principles; and address factors that can increase vulnerability to radicalization. Some focus on economic integration, seeking to facilitate access to employment and education for disadvantaged groups. Others use mentors and role models to positively influence youths. Various programs seek to promote self-awareness and critical thinking in young people. Few programs have an overtly religious focus. An example is the Radical Middle Way, a British Foreign Office-sponsored project that connects Muslim scholars with predominantly British Muslim youth. While youths are the main targets of these initiatives, others seek to engage parents and women in particular.

\footnotetext{
${ }^{34}$ Lorenzo Vidino and James Brandon, Countering Radicalisation in Europe, International Centre for the Study of Radicalization, King's College London, December 2012.

${ }^{35}$ For a detailed overview of some of the most recent CVE-related trends and initiatives throughout Western Europe, see Preventing Radicalisation to Terrorism and Violent Extremism: Strengthening the EU's Response, RAN

(Radicalisation Awareness Network) Collection: Approaches, Lessons Learned and Practices, First Edition, January 15, 2014.
} 
b) Outreach/engagement measures: These initiatives aim to improve communication and build trust between authorities and communities. Some target prominent community leaders, while others proactively seek to cast a wider net, even seeking to establish a dialogue with potentially hostile audiences. Danish officials, for example, have long visited schools with many Muslim students to explain and dispel misconceptions about Danish society and foreign policy. ${ }^{36}$ In some cases, authorities hope that establishing a trust-based relationship can also lead to increased intelligence originating from communities, though this is considered more a secondary and incidental byproduct.

c) Individual interventions: Rather than targeting large population cross-sections, these initiatives aim at "rehabilitating" people who appear to be radicalizing to violence. Countries that adopt such an approach invest resources in training a wide range of government employees and partners to recognize the common causes, risks, and manifestations of radicalization. Officials receiving training include police officers, educators, university administrators, health professionals, social workers, housing officers, prison guards, and probation officers. These individuals are then expected to detect potential cases of radicalization among individuals with whom they are in contact through their professional lives and refer them to authorities.

The body to which referrals are made varies from country to country. Under Great Britain's targeted intervention scheme, known as the Channel Programme, referrals go to coordinators appointed for each local government district. These coordinators usually have a police background (though increasingly less so). In various Dutch and Danish municipalities, on the other hand, law enforcement agencies are not directly involved in the process, as the units who run interventions are composed of civil servants, psychologists and, in some cases, former extremists.

Once the at-risk person has been identified and referred, the evaluating body assesses the severity of the risk. If authorities assess a genuine threat they craft targeted interventions aimed at swaying the individual away from militancy and back to a normal life. In most cases the intervention entails the designation of a mentor, somebody who already has or could potentially establish a trust-based relationship with the radicalizing individual. This process, which is constantly monitored by authorities, is complex and varies from case to case. Ideally the mentor steers the radicalizing individual away from violent extremism.

Over the last few years, European authorities have displayed diminished enthusiasm for large, preventive programs due to their high costs and difficulty in empirically determining effectiveness. Individual interventions are, on the other hand, increasingly popular because, conversely, they are cost-effective and easier to evaluate. For security and privacy reasons authorities are reluctant to provide hard data on intervention success rates. Nonetheless, officials throughout Europe consider targeted interventions an extremely useful complement to traditional counterterrorism tactics. While it is clear that interventions will not work in all cases, their threat

${ }^{36}$ A common and safe future, Government of Denmark, January 2009.

$-13-$

Program on Extremism - 2000 Pennsylvania Avenue NW - Suite 2210 - Washington, DC 20052 https://cchs.gwu.edu/program-extremism 
reduction effect is a much needed relief for Europe's overwhelmed law enforcement and intelligence agencies.

Over the last few months, targeted interventions have also been increasingly used in cases of aspiring and returning foreign fighters. Indeed, authorities in Europe face difficulties in obtaining evidence to prosecute those who seek to reach or return from Syria/Iraq or other battlefields, and monitoring the bulging numbers of aspiring militants and returnees. Thus, officials have increasingly resorted to one-on-one interventions as a last resort tool in their effort to tackle the challenge. In this regard, the approaches used by the German Hayat program ${ }^{37}$ and the Danish city of Aarhus ${ }^{38}$ have attracted particular attention.

Most European counterterrorism practitioners believe that at least some forms of CVE measures are important components of a comprehensive counterterrorism strategy. One-on-one interventions are seen as particularly useful tools and are being implemented in a growing number of European countries. American authorities are likely to draw some informative lessons from this relatively longer experience in CVE of European countries.

${ }^{37}$ Daniel Koehler, “Family Counseling as Prevention and Intervention Tool against 'Foreign Fighters.' The German 'Hayat' Program,” Journal EXIT-Deutschland, Issue 3/2013.

${ }^{38}$ Bharati Naik, Atika Shubert and Nick Thompson, "Denmark offers some foreign fighters rehab without jail time - but will it work?” CNN, October 28, 2014. 


\section{Challenges}

Authorities on both sides of the Ocean conceiving and implementing CVE initiatives are faced with several problems. Among them:

The complexity of the radicalization process. Unfortunately for policymakers and practitioners, radicalization is a highly individualized process. ${ }^{39}$ Efforts to simplify radicalization into a linear step-by-step process fail to recognize the complexity of the issue. As such, attempts to disengage from violence or even de-radicalize an individual must be tailored to that unique situation. Officials and community members must be flexible in their approaches, making it difficult to develop nationwide, general programs which in turn increases the difficulties of developing useful national programs and sharing best practices.

Finding partners. Over time, European authorities have understood that, in order to obtain the crucial support of various stakeholders, they need to explain their strategy and aims to the public, the categories of professionals with which they seek to work, and, in particular, the communities they aim to reach. Many potential partners, in fact, tend to be skeptical of the government's actions and refuse to cooperate or in some cases actively undermine counter-radicalization initiatives.

This problem was particularly acute in the UK, where a variety of stakeholders initially condemned CVE initiatives and, in particular, its intervention scheme (Channel) as tools to criminalize young people for their views. Outlining the case of Hasib Hussain, one of the July 7, 2005, London suicide/homicide-bombing perpetrators, Director General of the Office for Security and Counter Terrorism at the Home Office Charles Farr explained why interventions with radicalized individuals are conceived "precisely to avoid them criminalising themselves":

We started to unpick what was known about Hasib Hussain. He had never come to the notice of the police at any stage in his young life and therefore in terms of opportunities for the police to intervene to prevent what went on to occur, there were just no hooks there. However, what we did discover is that as a model student whilst at Matthew Murray School his exercise books were littered with references to al-Qaeda, and the comments could not have been taken as other than supportive comments about al Qaeda. To write in one's exercise book is not criminal and would not come on the radar of the police, but the whole ethos, the heart of Prevent is the question for me of whether someone in society might have thought it appropriate to intervene. What do I mean by intervention? I do not mean kicking his door down at 6 o'clock in the morning and

\footnotetext{
${ }^{39}$ See Anja Dalgaard-Nielsen, "'Violent Radicalization in Europe: What We Know and What We Do Not Know,' Studies in Conflict \& Terrorism, 33, no. 9 (2010): 797-814; Randy Borum, "Radicalization into Violent Extremism I: A Review of Social Science Theories,” Journal of Strategic Security, 2011, 4 (4): 7-36; Michael King and Donald M. Taylor, "The Radicalization of Homegrown Jihadists: A Review of Theoretical Models and Social Psychological Evidence,” Terrorism and Political Violence, 23:4, 2011, 602-622; Manni Crone and Martin Harrow, "Homegrown Terrorism in the West,” Terrorism and Political Violence, 23:521-536, 2011.
}

$-15-$

Program on Extremism - 2000 Pennsylvania Avenue NW - Suite 2210 - Washington, DC 20052 https://cchs.gwu.edu/program-extremism 
hauling him before the magistrates. I mean should someone have challenged that? They are the sorts of cases that get referred through the Channel scheme. ${ }^{40}$

Increasingly aware of the need to be more inclusive, European authorities have begun to describe their efforts using the language of protection or, as the British say, "safeguarding." Young people like teenage student Hasib Hussain who are undergoing a process of radicalization are seen as vulnerable individuals harming themselves and ultimately in need of help. Radicalization in this articulation is presented as a problem like gang recruitment, drugs, or pedophilia. Just as they would do if they detected young people falling prey to these social ills, community leaders and teachers have a duty to report cases of radicalization. This framing has become even more common over the last few months, as more and more cases of radicalization involve individuals in their teens or even pre-teens. Authorities have compared these instances of radicalization to cases of child abuse, with online recruiters likened to Internet pedophiles. ${ }^{41}$

Effectively training partners: It is not simple to set up a diffuse network of individuals with appropriate competences in effective intervention. A few hours of training cannot easily make teachers or street cops attuned to the intricate dynamics of radicalization. Because knowledge is a crucial element of an effective counter-radicalization initiative, clumsy actions caused by partners with limited competences can produce negative repercussions.

Complex Muslim Communities Dynamics: Counter-radicalization efforts cannot succeed without the help of Muslim communities. Yet Western Muslim communities are not monolithic. Authorities often struggle to identify whom to partner with from among myriad organizations, many of which compete against one another for political positioning. While dynamics change from country to country, choosing many local partners with roots in specific communities -rather than relying on one or two large national organizations -- is a more effective way to engage. Creating partnerships with multiple organizations is more likely to harness the full potential of Muslim communities without relying on a few self-appointed gatekeepers.

At the same time, issues of credibility and legitimacy are paramount. Which voices are listened to in the community and can deliver a credible message? In this regard, a particularly controversial matter in Europe is the role of individuals and organizations linked to various strands of Salafism or to the Muslim Brotherhood's ideological family. Should these "nonviolent Islamists" be partners of the government against radicalization? Are they part of the problem or part of the solution? Opinions on this matter are divided. ${ }^{42}$

Measuring effectiveness: Providing clear metrics that empirically evaluate a CVE program's effectiveness is difficult. The challenge is particularly acute for preventive programs, as it entails proving a negative: the number of individuals who did not radicalize because of the program. De-radicalization measures are themselves difficult to assess because determining when an

\footnotetext{
${ }^{40}$ H.C. Communities and L.G. Committee, Preventing Violent Extremism, Sixth Report of Session, March 8, 2010.

${ }^{41}$ Hayley Richardson, “ISIS ‘Using Paedophile Grooming Tactics’ to Lure Young Jihadi Brides,” Newsweek, March 16, 2015.

${ }^{42}$ Lorenzo Vidino, “Europe’s New Security Dilemma,” Washington Quarterly, 32, no. 4 (October 2009): 61-75. $-16-$ 
individual has become "rehabilitated" is rarely a clear-cut call. Moreover, even empirical results can be interpreted in different ways. Does a $50 \%$ positive rate in a de-radicalization program make it successful? Critics might well argue it does not, and journalists will most likely focus on those subjects who despite interventions went on to become terrorists. Yet law enforcement agencies might disagree, arguing that halving their workload is a remarkable achievement. 


\section{Recommendations}

In addition to challenges common to all Western countries, the U.S. has to grapple with additional obstacles in its quest to improve CVE efforts. Foremost among them is the lack of specifically allocated resources. At the recent White House Summit, President Obama defined terrorism and the implementation of CVE solutions as a "generational problem." 43 But he also acknowledged the lack of adequate funding for such endeavor. "We're going to step up our efforts to engage with partners and raise awareness so more communities understand how to protect their loved ones from becoming radicalized," noted the President. "We've got to devote more resources to these efforts.”

Resources devoted so far to CVE have been limited, and CVE units within each relevant agency remain understaffed. As a recent DHS-commissioned Homeland Security Advisory Council report noted, "within DHS and the federal government there is currently no dedicated budget, office, human capital or support dedicated full time to CVE" ${ }^{44}$ A chief architect of the administration's strategy, Quintan Wiktorowicz, has publicly called on the administration to increase funding for CVE. ${ }^{45}$ Similarly, Andrew Luger, the U.S. Attorney for Minnesota who has been active in developing a CVE framework in Minneapolis-St. Paul, has argued: “All of this requires money. We're going to be asking for as much as is available, and we're making it clear in Washington that funding is critical to support this program." ${ }^{46}$ If the U.S. government truly wants to engage in robust CVE, it will need to provide sufficient funding.

There is also no agency with top responsibility for leading CVE efforts. While DOJ, DHS, FBI, and NCTC have done an admirable job coordinating CVE despite poorly-scoped policy directives, the effort would benefit from clearer leadership. The administration should appoint one department as the lead for CVE efforts to ensure more focused programs and a single point of contact for public advocacy and congressional oversight.

Finally, the next steps in America's CVE efforts need to be clearly defined. Various signs indicate that authorities want to add targeted intervention to augment an initial approach based solely on community engagement. Introducing intervention measures as an as-needed alternative to traditional counterterrorism measures should be encouraged. But interventions can be counterproductive if conducted without a clear strategy and legal basis. Working with civil rights and civil liberties advocates, the government should provide guidance on minimum standards for intervention efforts. Such guidance should address the role of government and communities in

\footnotetext{
${ }^{43}$ President Barack Obama, remarks at the White House CVE Summit, February 18, 2015. Available at: https:/www.whitehouse.gov/the-press-office/2015/02/18/remarks-president-closing-summit-countering-violentextremism

${ }^{44}$ Homeland Security Advisory Council, Foreign Fighter Taskforce Interim Report, Spring 2015.

45 Quintan Wiktorowicz, “It’s Time to Fund Domestic Counter-radicalization,” Lawfareblog.com, June 8, 2014.

46 Juliet Eilperin, “Trying to Counter Extremism at Home US Faces a Risk: Sowing More Mistrust,” Washington Post, February 16, 2015.
} 
interventions for radicalized individuals, as well as the legal parameters of interveners who currently place themselves at risk of civil (if not criminal) liability if interventions go awry.

The U.S. does not need to replicate Europe's most ambitious CVE efforts, mostly because it faces a significantly smaller radicalization challenge than countries across the Ocean. General preventive measures, particularly those promoting socio-economic development, should be implemented only in limited cases, as American Muslim communities enjoy high levels of integration, with some notable exceptions (e.g., parts of the Somali community). Engagement and other trust-building initiatives are useful and should be continued. The most pressing need at this stage is for the administration to build a carefully crafted system for interventions that provides families, communities, and authorities a potential alternative to prosecution. While these initiatives are best implemented at the local level, they require a high-level framework and clear guidance from federal officials.

CVE is a delicate tool that, if properly implemented, can help sway young people away from radicalizing, therefore saving their lives and allowing law enforcement and intelligence agencies to better concentrate resources on those who have made the leap into violent militancy. The more ambitious CVE goals declared by the administration over the last few months are praiseworthy. But they need to be supported by a clear strategic vision, solid resources, and a precise legal framework. 


\section{Program on Extremism}

The Program on Extremism at George Washington University's Center on Cyber \& Homeland Security provides analysis on issues related to violent and non-violent extremism. The Program spearheads innovative and thoughtful academic inquiry, producing empirical work that strengthens extremism research as a distinct field of study. The Program aims to develop pragmatic policy solutions that resonate with policymakers, civic leaders, and the general public. 